Engineering Sustainability

Volume 170 Issue ES3

Towards long-term infrastructure system

performance

Blom and Guthrie
Proceedings of the Institution of Civil Engineers

Engineering Sustainability 170 June 2017 Issue ES3

Pages 157-168 http://dx.doi.org/10.1680/jensu.15.00035

Paper 1500035

Received 10/06/2015 Accepted 20/01/2016

Published online 10/03/2016

Keywords: management/municipal \& public service engineering/social impact

ICE Publishing: All rights reserved i

\title{
Towards long-term infrastructure system performance
}

Carron M. Blom MSc (Hons), FIPENZ, MRMLA, MRSNZ, MAMINZ PhD Candidate, University of Cambridge, Cambridge, UK (corresponding author: cmb216@cam.ac.uk)
Peter M. Guthrie OBE, FREng, FICE

Director, Centre for Sustainable Development, Department of Engineering, University of Cambridge, Cambridge, UK

Infrastructure is presenting some significant global challenges. One issue is that, while it is often seen as performing well, it tends to do so against only against limited terms of reference and short-term objectives. The available literature suggests that, to date, performance has largely been approached from the point of view of a project, or through addressing latent failures arising from specific sources of shock or failure. In contrast, the literature is sparse in which these matters are examined from the perspective of service-led delivery at the system level (the system comprising assets, projects and networks each at different stages of their life cycle and variously affecting one another as they develop, then age). Yet this is arguably the level relevant to, and the reality of, much of the realm of day-to-day public infrastructure management. This apparent gap in infrastructure research has been explored through a series of interviews that looked at different levels in organisations, sectors and countries. These interviews test the presumption that a problem therefore exists, and sought to identify some of the factors involved. In so doing, this research highlights an issue with the alignment between infrastructure governance and day-to-day operations, specifically the feedforward/feedback mechanisms that span the governance/operational interface.

\section{Introduction}

Infrastructure is critical to many aspects of society and the quality of life in communities (e.g. Dobbs et al., 2013; New Zealand Government, 2011; OECD, 2012). Often described by its fixed, physical assets or networks, infrastructure is typically long-lived structure, individual asset often having a design life of 50-100 years. As a network or a system, infrastructure can endure for centuries (Carreras and De Soto, 2013).

Public infrastructure is that used by or within the public realm, and in New Zealand (which is to be the focus of later case studies), it is generally in some form of public ownership (New Zealand Government, 2011: pp. 6-7). This can be managed at the local, city, regional or national level, forming networks and systems. Those systems will comprise assets or artefacts, projects and networks each at different stages of their life cycle and variously interacting and affecting one another as they develop, then age. The system simultaneously comprises numerous levels and relationships within the system itself, its functionality and the environment (in the broadest sense).

This creates a dynamic and complex environment, with inherently high levels of uncertainty. These are then 'evolutionary systems' (van der Lei et al., 2012: pp. 32-33), complete with the paradoxical elements that come with the introduction of social, functional and individual perspectives and perceptions (e.g. Atkinson and Moffat, 2005: p. 120; de Wit and Meyer, 2010: p. 114; Green, 1994: p. 52; Star, 1999: p. 380).
It is both the critical nature of infrastructure and the complex interdependencies that underline the significance of the global challenges now being presented by infrastructure. According to Dobbs et al. (2013), Durango-Cohen (2007), Fenner and Ainger (2014), Guthrie and Konaris (2012), Hall et al. (2013), OECD (2012) and Omega Centre (2012) for example, these include the following issues.

- Much 'new world' or post-war infrastructure is simultaneously approaching the end of its design life.

- Infrastructure is often poorly performing, or inadequate for current and future needs.

- Recent natural disasters have underlined the importance of infrastructure resilience.

Yet the catastrophic failure of infrastructure is relatively rare, and indeed, infrastructure may be perceived or reported as performing relatively well in a number of areas (e.g. New Zealand Government, 2011: p. 8). This may, however, only be the case when considered against a limited set of performance measures and frequently shortterm considerations (Brown et al., 2013; Controller and Auditor General, 2014: pp. 3-5; Fenner and Ainger, 2014: p. 204). Furthermore and irrespective of any reported good performance, there is also an identified need for ongoing improvement (Controller and Auditor General, 2014; New Zealand Government, 2011: p. 8).

Not surprisingly, the outcomes delivered by infrastructure are of growing importance, particularly those achieved by existing 
Towards long-term infrastructure system

performance

Blom and Guthrie infrastructure. The focus on outcomes in this context is underpinned by the development of 'new public management' in the public sector, which emphasises business-like performance and stakeholder collaboration (Dunleavy and Hood, 1994: p. 9; Hendriks and Tops, 1999: pp. 133-134, 2003: p. 301; Hood, 1991: p. 3; Lowndes, 1997: p. 44). However, infrastructurerelated literature in this area appears to be sparse. Almklov and Antonsen (2014: p. 1) provide one of the few examples to consider the implications of new public management on infrastructure practice. Significantly, they found that it 'renders essential aspects of operational work invisible - including practices that are known to be of importance for reliability'.

Some attention has been given to improving outcomes through project selection (e.g. Flyvbjerg, 2009; Flyvbjerg et al., 2003a). However, while of vital importance, overall performance requires more than the delivery of a programme of works. Crucially

- infrastructure governance systems have typically remained static despite their ability to effect positive change (Dobbs et al., 2013: p. 4)

- feedback within infrastructure practice is poor (Busby, 1998) and any differences between planned and actual project performance are frequently 'explained away as an isolated instance of unfortunate circumstance' (Flyvbjerg et al., 2003b).

Greater attention, therefore, needs to be paid to the alignment between strategic intent and the tactical reality of day-to-day infrastructure operations. As Edkins and Zerjav (2014: pp. 2-3) argue, the asset-based and service or provision-based typologies needs to be broadened to construct 'a novel concept of infrastructure and the management of its interdependencies that moves beyond the domain of engineering artefacts and includes interactions between actors, organizations and institutions'.

Some research has been undertaken in this area in relation to latent failures, and the associated analysis does provide one form of engineering and infrastructure feedback. Latent failures derive from factors that may not in themselves result in failure, that may take some time to become apparent or that may lie dormant until combining with other factors or circumstances (Reason, 1990: p. 28).

The effect of latent failure has been researched in the area of natural disasters (Desouza and Flanery, 2013: p. 94), catastrophic failure of infrastructure (e.g. Bolton et al., 2008; Reason, 1990) or emergent events such as climate change (Crabbé and Robin, 2006). Such studies consider the role of managerial and organisational processes but do so through a specific lens.

However, there are a few, if any, published studies that explore latent failures of 'business-as-usual' operations within the public infrastructure space and more particularly addressing such issues at a system level. This includes research into both the latent failure of the system and the positive flip side to this; system 'fitness' (to extrapolate Flyvbjerg, 2009). While the research may be germane to business as usual operations, it is seeking either specific root causes or outcomes relative to a specific event. As Schön (1991: p. 9) has observed

A series of announced national crises - the deteriorating cities, poverty, the pollution of the environment, the shortage of energy, seemed to have roots in the very practices of science, technology, and public policy that were being called upon the alleviate them.

Of the research that does exist in this area, most examine the problem from within the classical optimisation paradigm (for example as outlined by Durango-Cohen, 2007: p. 494); this includes those studies that consider departure from procedures as error or violations, rather than considering the suitability of the procedures themselves (e.g. Goodman and Ramanujam, 2012; Reason, 1995). The closest comparable research is that from the healthcare sector (e.g. Laxmisan et al., 2007; Lederman and Parkes, 2005; Mead and Bower, 2000); however, these too tend to focus on the identification of specific sources or error (e.g. Cosby, 2003).

Much of the current infrastructure literature also examines issues through a project centric lens. This presupposes a conventional asset life cycle of plan, build, maintain and dispose and examines the issues with the implicit presumption of building more projects and then optimising the hard assets. There is a need, then, to understand if, where and how a breakdown in the business-asusual management of infrastructure is occurring and how this might then affect strategic decision-making or infrastructure governance.

- 'We often have quite messy, poorly structured situations where objectives are not clear, where different constituencies have conflicting aims and where the way forward requires vision and leadership as well as hard analysis and design' (Morris, cited by Winter et al., 2006: p. 645).

n 'Whilst the traditional engineering research methods are valuable to study the physical artefacts of infrastructure, such methods clearly have limitations in addressing the complexities that arise from social, financial, power, and other kinds of relations between different human actors and organizations that enact the web of infrastructure phenomena' (Edkins and Zerjav, 2014: p. 13).

- 'Such problems can no longer be solved by the application of still more "engineering fixes" nor are they amenable to the conventional remedies of human factors specialists... These ... depend upon acquiring a better understanding of the breakdown of complex socio-technical systems, and the development of new techniques of risk assessment' (Reason, 1990: p. 28).

This paper explores some of these issues from the perspective of the infrastructure system itself, in which new projects emerge and change the existing system of assets, projects, networks and the services that these deliver to their community. The focus is on 
Engineering Sustainability

Volume 170 Issue ES3
Towards long-term infrastructure system

performance

Blom and Guthrie business as usual operations and, in particular, the context that this creates for governance and long-term infrastructure outcomes. This broad canvas was narrowed through a series of cross-sector industry interviews that sought to better refine and understand the problem and to focus areas for possible future research.

\section{Infrastructure inquiry}

\subsection{Overarching approach}

To respond to an apparent gap within the literature, the research comprised a series of semi-structured interviews conducted with the aim of identifying key issues and therefore the research 'problem space' (i.e. to address the high-level questions of whether there is a problem and, if so then, what are its characteristics and where should the researchers look further?). The approach comprised two stages as follows.

- The interviews were firstly across a range of infrastructurerelated organisations, and were focused on determining whether there is a problem and identifying the broad nature of that problem. This stage sought to understand this through a series of generalised questions that probed infrastructure as both an artefact and a social enterprise. Appreciative enquiry was also used to canvas areas of existing practice that worked well. Interviewees included chairpersons/board members, chief executive officers, directors, executive management and senior specialists. A total of 32 New Zealand interviews were conducted along with a limited number (eight) in the UK and Europe, covering a total of 33 different organisations.

- The second stage sought further detail on areas or issues (and conversely opportunities) meriting closer examination. To do so, it targeted one infrastructure sector: transportation. This stage excluded matters within the project delivery process (which is already well served by literature), looking instead at the wider operational system and its interfaces and feedback processes. Interviews were conducted both vertically from chairpersons/board members to team leaders and also with those that operate across the organisation (disciplinary specialists and cross-departmental functional areas). A further 19 interviews were held within a large New Zealand municipal transportation organisation.

A summary of the expertise and experience covered by all 59 interviews is given in Table 1. For completeness, it is noted that political aspects and interfaces were excluded. Infrastructure governance, therefore, refers to executive board-level functions (which may include some political appointees), as distinct from political stewardship, where the executives report directly to elected officials.

\subsection{Sector selection}

Prior to embarking on the interviews, consideration was given to the selection of the infrastructure sector used within the second stage of interviews. As this then informed the overarching approach, it has been included here for completeness and context.
The New Zealand infrastructure environment provides the opportunity to investigate the alignment of governance and operations at the system level. New Zealand's infrastructure remains largely in public ownership, and there is a separation (or at least an awareness of the need to separate) political stewardship from technical and organisational governance (Auckland Transport, 2014: pp. 11-13; Controller and Auditor General, 2002).

While this research conceivably has a broader application, it was also decided to use municipal (land) transportation systems as the focus for more detailed investigation. The choice of this sector was in part influenced by researcher experience and knowledge of the processes across the life cycle of projects and systems in this area. Industry access was also a consideration.

More materially, land transport was identified as a potential sentinel in the overall understanding of decision-making for infrastructure. This was primarily because land transport, more than other infrastructure types, influences society through its interface with land use and economic development and is frequently a conduit for other types of infrastructure (Carreras and De Soto, 2013; p. 117; Dennis, 2008: pp. 113-115; Martindale in Weber, 1958: pp. 16, 25; Zylstra, 2013: p. 3). Indeed, Martindale (in his preface to Weber, 1958: p. 57) expands

'The street, represents first and last the greatest material problems of the city for here the cooperation of the whole community, a free way is provided, an "open road", a challenge for traffic and transportation for all alike'.

Martindale goes on to quote Henri Pirenne's declaration that 'the control of the streets means the control of the city' (cited in Weber, 1958: p. 58).

The land transport sector also provides an example of the transition rapidly developed infrastructure systems must now undergo to confront matters such as simultaneously ageing assets, the full realisation of maintenance costs and ongoing growth. Furthermore, there is an identified need for further development of long-term infrastructure system performance within this sector (e.g. Controller and Auditor General, 2014; Institution of Professional Engineers New Zealand, 2010).

\section{Common threads and stories}

Coded data from all of the interviews are presented in Figure 1. While these were inevitably guided in part by the structure of the interview, they nonetheless provide a useful road map of the common topics within those discussions. So, while the six key thematic areas to emerge at this level (Table 2) reflect the interviewing framework, of more interest are the common threads and thematic patterns to emerge from the views of a diverse, yet highly experienced group of infrastructure practitioners. In particular, this highlights the interaction between infrastructure outcomes and organisational decision-making, performance monitoring and learning, in short, the 'missing' feedback loop 


\section{Sector}

Social infrastructure

Recreation

Healthcare/public health

Education

Energy

\section{Generation \\ Transmission \\ Distribution}

Transport

State highway

Local roads

Rail

Public transport

Sea and air ports

Telecommunications

Waters

Water

Waste water

Storm water

Wastes

Defence

\section{Role}

Central government

Funding and finance

Statutory

Political

Governance

Client

Consultant

Contractor

Stakeholders

Director

Manager

Team

Policy and strategy

Asset management

Project delivery

Operations

Compliance/audit

Industry organisation

Emergency preparedness

Aid

Academia/research

\section{Discipline}

Engineering

Sciences

Planning

Law

Other arts

Finance and business

$\boxplus$

Other expertise (e.g. cultural)

\section{Context (NZ only)}

MoW

Post-MOW (1988+)

\section{Location}

Auckland

NZ

Australia

Pacific Islands

Greater Asia

Europe and UK

Americas

Africa

Other/unspecified
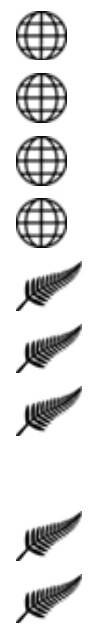

$\bigoplus$
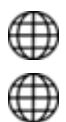



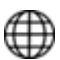

Note that this records experience based on current interviewee location and does not infer nationality. Political factors are outside this research scope

NZ, New Zealand; MoW, Ministry of Works;

NZ-based interviewees; $\cdots$, EU-based interviewees; $\bigoplus$, com common experience

Table 1. Summary of interviewee experiences

alluded to by Busby (1998), Flyvbjerg et al. (2003b) and Lenferink et al. (2008).

Finally, regression analysis of overlapping codes (node correlation) has provided another way of looking at the threads. Table 3 documents the key associations or clusters using the dominant themes shown in Figure 1. These in turn have been sorted into thematic groupings (so the summary descriptions may not necessarily be found in the details of Figure 1). This in turn indicated three primary areas of note

- decision-making

- managing change

reconciling outcomes with objectives (feedback).
Resilience is also a key, but less dominant topic. Resilience is a matter that has recently come to the fore as a consequence of recent natural disasters, particularly in New Zealand (e.g. MacAskill and Guthrie, 2015), so its emergence at this level is not unexpected.

Table 3 also highlights the interdependencies and complexities of the threads at two levels.

- Intercluster relationships: There is some overlapping or similarity of keywords between groupings.

- Interthematic relationships: Clusters have been numbered according to proximity and sequence within the larger nested relationship tree. The mixed numbering 




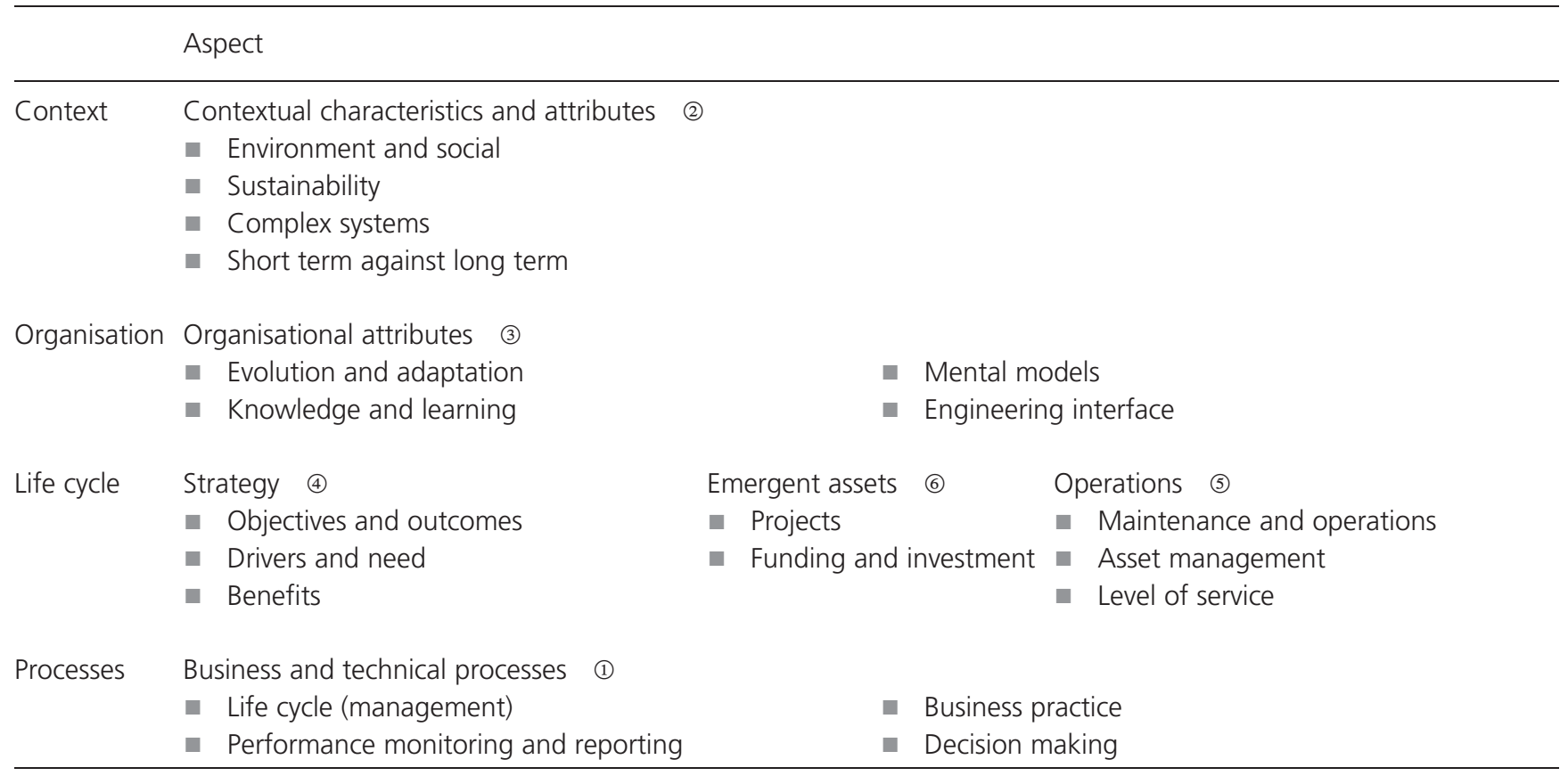

Circled numbers denote ranking of thematic area based on coded weighting 


\section{Decision-making}

4

5

8

9

10

\section{Managing change}

7

13

\section{Reconciling outcomes with objectives}

2
- Judgement

- Thought leadership

- Opportunities

- Scope

- History and legacy

- Political interface

- Structure of public infrastructure ownership

- Interdependence

- Prioritisation

- Interfaces

- Assumptions

- Mental models

- Perception and perspective

- Eroded outcomes

- Issues and risks

- Barriers

- Scale

- Accountability

- Convention, tradition and belief systems

- Education and training

- Big picture thinking

- Incrementalism

- Choice

- Uncertainty

- Disaster and shock

- Resilience

- Technology

- Change

- Dynamic systems

- Policy and planning

- Context

- Drivers and need

- Lock in

- Developer interface

- One size fits all

- Urban against rural or small

- New Zealand infrastructure context

- Collaboration

- Joined-up thinking

- Communications

- Aptitude and willingness

- Culture

- Business practice of infrastructure

- Organisation

- Inputs and clarity of brief

- Client/adviser interface

- Contextual awareness

- Procurement

- Benevolent dictatorships

- Longevity and continuity

- Life cycle

- Short term against long term

- Environment and social

- Sustainability

- Flexibility and optionality

- Forecast and foresight

- Buy-in and alignment

- Strategy

- Conversations and relationships

- Evolution and adaptation

- Ownership of resources

- Capacity and capability

- Growth and development

- Behaviour

- Theory against practice

- Feedback, review, questioning

- Knowledge and learning

- Integrated, holistic, inclusive

- Complex systems

- Decision-making

- Customer focus

Table 3. Correlating themes (continued on next page) 


\begin{tabular}{|c|c|c|c|c|}
\hline \multirow[t]{5}{*}{11} & घ & Renewals & घ & Emergence \\
\hline & घ & Front end & - & Latent failure factors \\
\hline & घ & Modelling & घ & Story telling \\
\hline & घ & Transparency & घ & Follow-through \\
\hline & & & घ & Disconnects \\
\hline \multirow[t]{8}{*}{12} & घ & Economic benefit & घ & Benefits \\
\hline & घ & Land use & घ & Objectives and outcomes \\
\hline & घ & Asset management & घ & Performance monitoring and reporting \\
\hline & घ & Maintenance and operations & घ & Innovation \\
\hline & घ & Future proof & घ & Fitness \\
\hline & घ & Function & घ & Vision and aspirations \\
\hline & घ & Processes and operating framework & घ & Values and value \\
\hline & घ & Legislative context & घ & Consequences \\
\hline \multicolumn{5}{|c|}{ Resilience } \\
\hline \multirow[t]{4}{*}{14} & घ & Efficient design & घ & Brittleness and vulnerability \\
\hline & घ & Repurposing & घ & Failure \\
\hline & घ & Appropriateness & घ & Redundancy \\
\hline & घ & Robustness & & \\
\hline
\end{tabular}

Table 3. Continued

sequence within each of the themes is therefore indicative of the interrelationships between clusters and themes.

Again, these clusters and themes are not necessarily indicative of issues. These layers of interwoven interdependence do, however, serve to underline the importance of considering the conceptual complexities at the issue level.

\section{Is there a problem and what is the nature of that problem?}

While the available literature did suggest a research gap, this does not, of course, necessarily equate to a problem in reality. Indeed, some of those interviewed did feel that they (team/organisation/ sector) were performing well, although acknowledging the need for ongoing improvement. There was a general observation among those interviewed, however, that good performance was patchy (e.g. between sectors, organisations and projects and over time). So, even where areas of good practice were identified (e.g. recent improvements in the rate of delivery of projects to the construction market, project procurement and asset management), other individuals would have a different perspective and could point to where these were incomplete or could improve. The interviews provided a good degree of triangulation in this regard and again reinforced the differences between theory and practice and of the importance of perception and perspective.

The interviews also unearthed a series of belief systems in more than one organisation, whereby one part of an organisation believed something had been addressed by another (in contrast with the subject department's own view that their practice was very rudimentary or essentially non-existent). Similar issues have also been flagged by the New Zealand Office of the Auditor General

\footnotetext{
'All but one of the 31 local authorities revalue their infrastructure assets either annually or every three years. Most consider their valuation data to be reliable. This means that most of the data is based on sound records and has been adequately documented. However, the data might have minor shortcomings (such as some old or missing data)' (Controller and Auditor General, 2014: p. 30).
}

More widespread than the sense of industry 'well-being' was the feeling that, from the perspective of those within the industry, there is indeed a problem and the overall outcomes were suboptimal in some way. While there may be many reasons contributing to this, the crux of the problem, or the primary issue to arise at this time, is the inability to fully deliver appropriate and relevant infrastructure outcomes over the long term.

'I mean if you put a bunch of engineers in charge of a project, they'll do a fantastic job of delivering you a project, but you know, that may not actually deliver what you want to see! 'Cos they're focussed on design and implementation and doing and all of that good stuff mission critical - but if you haven't got your problem definition and solutions sorted out in the first place, you end up with the sorts of problems that we, you know, we've just had a long discussion on!'

Much has been written from a management perspective as to the challenges in implementing strategy and aligning day-to-day management or tactical operations with strategic intent. Attention 
has also been given to the matter of infrastructure project selection and factors that promulgate poor project selection and outcomes. Yet infrastructure operational matters have received relatively little attention. While infrastructure might not catastrophically fail in the short term, as Hellström (2007: p. 417) observes, 'Disruption does not come about through expansion of a system, but rather because incremental change may embed design flaws gradually deeper into a system, where ad hoc solutions to improve workability hide problems under increasingly thick layers of technological "improvements", yet do not eliminate them'.

From the perspective of those being served by infrastructure, the problem is a significant one. For example in New Zealand local government, where infrastructure related services are a vital part of council function, a recent survey of some 2400 residents and 594 businesses found that, while the results might generally be 'good' and indirectly comparable to those of countries such as Australia and the UK, this was of 'little comfort' (Local Government New Zealand, 2015: pp. 3, 15). This was because, among other feedback, respondents rated local government performance at 28 out of 100 (Local Government New Zealand, 2015: p. 9). The Institution of Professional Engineers New Zealand (2010) has reported similarly degraded customer feedback in other infrastructure sectors.

While there is no suggestion of catastrophic failure, both the interviews and abovementioned reports point to a more insidious issue of omission and unrealised potential, of society working around its infrastructure. So while the primary issue might be very simple to articulate, it is paradoxically complex. In this vein, four key problem dimensions emerged

needs: what is delivered and how it is delivered

- precepts: what customers believe or expect to be delivered

- choices: whether the choices are appropriate and purposeful, and that compromises have been understood

- aptitudes: whether or not there is the ability to both proactively and reactively change.

Much infrastructure literature currently focuses on doing the right projects right. Yet the emergent dimensions show that there is more to the problem space than addressing 'need'. Furthermore, while there was a shared awareness of the importance of improving longterm infrastructure outcomes at senior levels, benefit management also seemed to be somewhat the elephant in the room. Because a piece of infrastructure has not fallen down and may 'only' be perceived as (i.e. not 'actually') a problem does not mean that the issue is neither real nor significant as there are more dimensions to the issue than indicated by the hard infrastructure assets alone. Infrastructure customers often have little or no choice in where they go for infrastructure services and may not be heard over technical and funding considerations. These are the matters of stakeholder salience and legitimacy developed by Mitchell et al. (1997) in response to the work of Freeman (e.g. Freeman, 1994; Freeman and Evan, 1990). And yet, as the industry anecdote goes, there is no point building good quality concrete life jackets.

\section{Generalisability of the data}

One of the common questions asked of interviewees was whether the issues being raised related solely to the instance described (circumstances or organisation) and whether this was a countryspecific issue. It would be very easy to dismiss the feedback summarily for these reasons. Such throwaway lines do present a challenge to research of this nature and so are worth discussing upfront.

Interviewees responded to enquiries of this type by affirming the generic nature of the examples being given or the issues raised. Many of those interviewed had worked in more than one country and a variety of different contexts and had experienced common themes across these. Their feedback suggests that it is not just poor organisational, sector-specific or country-specific practice and that the issues are worthy of being explored further. Comments particularly emphasised differences between theory and practice and how some of the issues stem from an expectation or perception that practice occurs by the book. The feedback, however, also pointed to the timeliness of such discussions, suggesting that there was now an appetite to start exploring and addressing some of the complex problems being faced in infrastructure management.

\section{Contributing factors}

A great many reasons were identified for the issue with long-term infrastructure outcomes, providing an insight into where to look further.

- Knowledge is not being retained within the system (feedforward) and then feeding back to inform future decisions as best it might. This also exacerbates the degradation of levels of service, asset life and other outcomes.

- Infrastructure management (organisational structure, focus and processes) is still heavily focused on capital work delivery, and processes tend to be asset oriented. Consequently, systemlevel benefits are rarely monitored and therefore can be absent from decision-making processes.

- Projects or organisational functions are often ring-fenced, and consequential projects or operational implications (including opportunities) are not often followed through nor are competing priorities resolved (this also extended to intraorganisational issues). Staff rarely move through the infrastructure life cycle to see first hand the implications of their decisions.

- Projects are being delivered to operations, but the operational framework rarely adjusts to accommodate changes arising to the system (either to the hard system or those within the organisation such as specifications in the case of non-standard assets). In turn, operational implications were not typically (and/or transparently) available to future strategic decision makers (see the first reason).

- Long-term thinking that integrates physical assets and organisations at the system level was often seen as a missing necessity, along with an overarching need to improve decision-making in complex, dynamic environments. 
Engineering Sustainability

Volume 170 Issue ES3
Towards long-term infrastructure system

performance

Blom and Guthrie
However, system-level issues are not as well understood as project issues, and little attention is given to the long-term evolution of existing systems.

These align with a number of significant life cycle transition or interface gaps, as summarised in Table 4 and alluded to in part by Edkins and Zerjav (2014: p. 8). In addition, the interviews also suggested a need to improve processes so that these are focused

- internally to address organisational capability and capacity

- externally to include infrastructure in its context (the scope needs to provide for the social rather than just the technical outcomes and diversified to address often overlooked multifunctional, non-standard assets or outcomes)

- at the system level and on the long-term function of the combined whole rather than individual assets.

Many of these factors stem from the matter of benefit management: the setting of objectives, their migration through project delivery and operational processes (feedforward), their appraisal and re-evaluation and feedback into system-level strategy and decision-making. The challenge that arises in turn is that, while much needed, applying a project management or business framework to certain parts of the process is unlikely to address any issues arising from system complexity and interdependencies (Edkins and Zerjav, 2014: p. 13). Moreover, any approach needs to provide for the dynamic context and long time frames over which this occurs. Consequently, while the interviews show that there are any number of facets to this area, this is less a series of problems to be solved than an ecosystem to be understood.

\section{Discussion}

Bosch et al. (2013: p. 116) are of the view that 'despite many efforts to deal with these complex issues facing our society, the solutions so far have seldom been long lasting, because "treating the symptoms" and "quick fixes", using traditional linear thinking, are the easiest way out, but do not deliver the solutions'. There is no one solution to a complex problem or problem within a complex system; instead, it is a matter of identifying, and to again draw on the words of Bosch et al. (2013: pp. 116, 134), 'leverage points for systemic interventions'.

The strategic importance of infrastructure cannot be over stated. Yet it is presenting significant national and global challenges. One issue is that, while often seen as performing well, it tends to do so against only against limited terms of reference and short-term objectives. Given that the world is facing a new infrastructure bill of some $£ 40$ trillion, improving the benefits delivered by existing infrastructure is vitally important (Dobbs et al., 2013). This is not just a matter of optimisation, however.

While the overarching issue relates to the long-term performance of infrastructure and thence the alignment of infrastructure governance and operations, this really amounts to how organisational structure and business practice define or shape engineering decision-making and infrastructure outcomes. Benefit management and the related feedforward and feedback processes probe and transect this space and have been highlighted as areas for further investigation and possible leverage. As one interviewee observed:

'.. there is no current process in place to verify that the benefits that we anticipate ... [are delivered] so we don't do benefits management well. So although the benefits of a project are defined at the planning and early design stage they are not measured efficiently ... during the detailed design, construction and certainly not after the project has finished'.

The lack of attention being paid to understanding system-level benefits, their relationship to decision-making and the associated implications of an absent feedback loop also has flow on effects into areas such as the ability to manage change and resilience.

Because of the range of possible disconnects within the system (as described), as well as the time frames involved, the loss of benefits may not be immediately apparent. A number of those interviewed talked of 'legacies' resulting from past infrastructurerelated decisions and management choices. Some but not all of

Aspect (life cycle stage)

Contributing factors

\begin{tabular}{lll}
\hline $\begin{array}{l}\text { Strategy/project } \\
\text { interface }\end{array}$ & $\begin{array}{l}\text { Articulating benefits } \\
\end{array}$ \\
& Business case boundaries \\
& Lock-in/momentum/prioritisation \\
& Follow-through/reconciliation with system-level objectives (feedforward) \\
Project/operational & Handover (feedforward) \\
interface & Transition from asset to system \\
& Whole-of-life performance \\
Operational/strategy & Performance (benefit) monitoring \\
interface & -
\end{tabular}


Towards long-term infrastructure system

performance

Blom and Guthrie these referred to examples prior to local government restructuring in Auckland. Every example, however, referred to infrastructure that was less than a century old and therefore notionally within its design life. From the perspective of those managing the infrastructure, this might be viewed as a latent failure. From the perspective of the long-lived infrastructure itself, it is perhaps more of an active failure. Either way, it is not achieving the outcomes intended, but this cannot be known for sure when system-level benefits are not re-evaluated or tracked. As was noted earlier, this in itself raises a challenge in the balance between looking back to feedforward within a dynamic environment.

Some of those interviewed suggested that this was perhaps an asset management issue and could therefore be addressed within existing practice. More often, however, it was held that a different approach was required. This was clarified by one interviewee, thus:

\footnotetext{
'It's more than asset management ... asset management is quite simply what do you own, what condition is it in, and how much money do I need to spend ... to keep it going. This is about looking and predicting future costs and future impacts and looking at how capital new works and the benefits that they - in the business case - actually roll out and are affordable in terms of maintaining and renewing that new asset'.
}

One of the underlying themes was also the inappropriateness of the dominant project-centric approach to infrastructure management; interviewees noted that this extended beyond the "'executionorientated" mind-set' during project delivery identified by Edkins and Zerjav (2014: p. 15), the linear pipeline of conventional asset life cycles being ultimately unhelpful to managers immersed in a system of concurrent and overlapping processes and systems. A new mental model is therefore needed, in the least for approaching this research space. The system life cycle proposed by Blom (2014: p. 15) offers a possible alternative lens and starting point from which this problem space may be considered and the higherlevel implications better understood.

\section{Conclusions}

This research has confirmed a system-level problem with current infrastructure practice that is inherently expressed within the current exhortation to make better use of existing infrastructure. Although not often catastrophically failing, the current infrastructure is not performing as expected nor as best it might despite the development of innovative engineering and tools to assist the efficient and effective management of assets.

Usefully, the 59 interviews collectively demonstrated that the issues were not singular to any one organisation, infrastructure sector or country. These have also identified benefit management (albeit at the system level and at the interfaces between operations and governance and the role of projects in transforming these) as an area worthy of further investigation as a potential leverage point for change. What is also clear is that, while strategic planning, project management and asset management are useful frameworks for their respective life cycle stages, there are still outstanding implementation issues and furthermore, infrastructure systems operate across all these simultaneously on a day-to-day basis. Therefore, it is the interfaces between these phases and their frameworks that provide an opportunity to look at the issue of long-term infrastructure outcomes through different lenses (Ackoff, 1994; Snowden and Boone, 2007) and across both macro- and micro-organisational levels (Van de Ven, 1976: p. 65). This is, however, still a 'wickedly' complex space in which there is sparse literature. There appears, however, an emerging appetite across a range of infrastructure sectors to now start tackling these matters, which provides a dynamic environment to engage in, and to research, an emergent area as it develops.

\section{Acknowledgements}

The authors are grateful to those who willingly shared both their time and their industry insights.

\section{REFERENCES}

Ackoff R (1994) Systems thinking and thinking systems. System Dynamics Review 10(2-3): 175-188, http://dx.doi.org/10.1002/ sdr.4260100206.

Almklov P and Antonsen S (2014) Making work invisible: new public management and operational work in critical infrastructure sectors. Public Administration, http://dx.doi.org/ 10.1111/padm.12069.

Atkinson S and Moffat J (2005) The Agile Organization: from Informal Networks to Complex Effects and Agility. Information Age Transformation Series, Command and Control Research Program, Washington, DC, USA, p. 22.

Auckland Transport (2014) Statement of Intent 2014-2017. Auckland Transport, Auckland, New Zealand.

Blom C (2014) A journey to KAOS: tackling 'wicked' infrastructure. 20th International Conference on Urban Transport and the Environment, Portugal.

Bolton ML, Bass EJ and Siminiceanu RI (2008) Using formal methods to predict human error and system failures. Proceedings of the 2nd International Conference on Applied Human Factors and Ergonomics.

Bosch OJ, Nguyen NC, Maeno T and Yasui T (2013) Managing complex issues through evolutionary learning laboratories. Systems Research and Behavioral Science 30(2): 116-135, http://dx.doi.org/10.1002/sres.2171.

Brown M, Clarkson B, Barton B and Joshi C (2013) Ecological compensation: an evaluation of regulatory compliance in New Zealand. Journal of Impact Assessment and Project Appraisal 31(1): 1-11, http://dx.doi.org/10.1080/14615517. 2012.762168 .

Busby J (1998) The neglect of feedback in engineering design organisations. Design Studies 19(1): 103-117, http://dx.doi. org/10.1016/S0142-694X(97)00028-8.

Carreras C and De Soto P (2013) The Roman transport network: a precedent for the integration of the European mobility. Historical Methods: a Journal of Quantitative and Interdisciplinary History 46(3): 117-133, http://dx.doi.org/10. 1080/01615440.2013.803403. 
Engineering Sustainability

Volume 170 Issue ES3
Towards long-term infrastructure system

performance

Blom and Guthrie
Controller and Auditor General (2002) Managing the Relationship between a Local Authority's Elected Members and Its Chief Executive. Office of the Auditor-General, Wellington, New Zealand.

Controller and Auditor General (2014) Water and Roads: Funding and Management Challenges. Office of the AuditorGeneral, Wellington, New Zealand, p. 65.

Cosby KS (2003) A framework for classifying factors that contribute to error in the emergency department. Annals of Emergency Medicine 42(6): 815-823, http://dx.doi.org/10. 1016/S0196-0644(03)00635-8.

Crabbé P and Robin M (2006) Institutional adaptation of water resource infrastructures to climate change in Eastern Ontario. Climatic Change 78(1): 103-133, http://dx.doi.org/10.1007/ s10584-006-9087-5.

de Wit B and Meyer R (2010) Strategy: Process, Content, Context: an International Perspective, 4th edn. South-Western Cengage Learning Australia, Hampshire, UK.

Dennis R (2008) Cities in Modernity: Prepresentations and Productions of Metropolitan Space, 1840-1930. Cambridge University Press, Cambridge, UK.

Desouza KC and Flanery TH (2013) Designing, planning, and managing resilient cities: a conceptual framework. Cities 35(0): 89-99, http://dx.doi.org/10.1016/j.cities.2013.06.003.

Dobbs R, Pohl H, Lin DY et al. (2013) Infrastructure Productivity: How to Save \$1 Trillion a Year. McKinsey Global Institute, p. 100. See http://www.mckinsey.com/insights/ engineering_construction/infrastructure_productivity (accessed 15/02/2016).

Dunleavy P and Hood C (1994) From old public administration to new public management. Public Money \& Management 14(3): 9-16, http://dx.doi.org/10.1080/09540969409387823.

Durango-Cohen PL (2007) A time series analysis framework for transportation infrastructure management. Transportation Research Part B: Methodological 41(5): 493-505, http://dx. doi.org/10.1016/j.trb.2006.08.002.

Edkins A and Zerjav V (2014) A policy program on infrastructure interdependencies: implications for front-end project management and opportunities for research. Proceedings of the Engineering Project Organization Conference, 29th-31st July 2014, Colorado. See http://www.epossociety.org/EPOC2014/ Papers/Edkins_Zerjav.pdf (accessed 15/02/2016).

Fenner R and Ainger C (2014) Sustainable Infrastructure: Principles into Practice. ICE, London, UK.

Flyvbjerg B (2009) Survival of the unfittest: why the worst infrastructure gets built - and what we can do about it. Oxford Review of Economic Policy 25(3): 344-367, http://dx.doi.org/ 10.1093/oxrep/grp024.

Flyvbjerg B, Bruzelius N and Rothengatter W (2003a) Megaprojects and Risk: an Anatomy of Ambition. Cambridge University Press, Cambridge, UK.

Flyvbjerg B, Skamris Holm M and Buhl S (2003b) How common and how large are cost overruns in transport infrastructure projects? Transport Reviews 23(1): 71-88, http://dx.doi.org/10. 1080/01441640309904.
Freeman RE (1994) The politics of stakeholder theory: some future directions. Business Ethics Quarterly 4(04): 409-421, http://dx.doi.org/10.2307/3857340.

Freeman RE and Evan WM (1990) Corporate governance: a stakeholder interpretation. Journal of Behavioral Economics 19(4): 337-359, http://dx.doi.org/10.1016/0090-5720(90) 90022-Y.

Goodman PS and Ramanujam R (2012) The relationship between change across multiple organizational domains and the incidence of latent errors. The Journal of Applied Behavioral Science 48(3): 410-433, http://dx.doi.org/10.1177/ 0021886311428435 .

Green S (1994) Beyond value engineering: smart value management for building projects. International Journal of Project Management 12(1): 49-56, http://dx.doi.org/10.1016/ 0263-7863(94)90009-4.

Guthrie P and Konaris T (2012) State of the World Report 2012: Sustainable Infrastructure, FIDIC. See http://fidic.org/books/ state-world-report-2012-sustainable-infrastructure (accessed $15 / 02 / 2016$ ).

Hall J, Henriques J, Hickford A and Nicholls R (2013) Systems-ofsystems analysis of national infrastructure. Proceedings of the ICE - Engineering Sustainability 166(5): 249-257, http://dx. doi.org/10.1680.

Hellström T (2007) Critical infrastructure and systemic vulnerability: towards a planning framework. Safety Science 45(3): 415-430, http://dx.doi.org/10.1016/j.ssci.2006.07.007.

Hendriks F and Tops P (1999) Between democracy and efficiency: trends in local government reform in the Netherlands and Germany. Public Administration 77(1): 133-153, http://dx.doi. org/10.1111/1467-9299.00147.

Hendriks F and Tops P (2003) Local public management reforms in the Netherlands: fads, fashions and winds of change. Public Administration 81(2): 301-323, http://dx.doi.org/10.1111/ 1467-9299.00348.

Hood C (1991) A public management for all seasons? Public Administration 69(1): 3-19, http://dx.doi.org/10.1111/j.14679299.1991.tb00779.x.

Institution of Professional Engineers New Zealand (2010) Assessing the State of Infrastructure: Is What You See What You Get?. Institution of Professional Engineers New Zealand, Wellington, New Zealand.

Laxmisan A, Hakimzada F, Sayan OR et al. (2007) The multitasking clinician: decision-making and cognitive demand during and after team handoffs in emergency care. International Journal of Medical Informatics 76(11): 801-811, http://dx.doi.org/10.1016/j.ijmedinf.2006.09.019.

Lederman R and Parkes C (2005) Systems failure in hospitals using Reason's model to predict problems in a prescribing information system. Journal of Medical Systems 29(1): 33-43, http://dx.doi.org/10.1007/s10916-005-1102-2.

Lenferink S, Tillema T and Arts J (2008) The potential of a lifecycle approach for improving road infrastructure planning in the Netherlands. Bijdrage aan het colloquium vervoersplanologisch speurwerk, Santpoort, Netherlands. 
Towards long-term infrastructure system

performance

Blom and Guthrie
Local Government New Zealand (2015) We Are. Local Government New Zealand, Wellington, New Zealand. See http://www.lgnz.co.nz/assets/In-background/LGNZ-2015Survey-Report-FINAL2.pdf (accessed 15/02/2016).

Lowndes V (1997) Change in public service management: new institutions and new managerial regimes. Local Government Studies 23(2): 42-66, http://dx.doi.org/10.1080/ 03003939708433864.

MacAskill K and Guthrie P (2015) A hierarchy of measures for infrastructure resilience - learning from post-disaster reconstruction in Christchurch, New Zealand. Civil Engineering and Environmental Systems 32(1-2): 130-142, http://dx.doi.org/10.1080/10286608.2015.1022728.

Mead N and Bower P (2000) Patient-centredness: a conceptual framework and review of the empirical literature. Social Science and Medicine 51(7): 1087-1110, http://dx.doi.org/10. 1016/S0277-9536(00)00098-8.

Mitchell RK, Agle BR and Wood DJ (1997) Toward a theory of stakeholder identification and salience: defining the principle of who and what really counts. Academy of Management Review 22(4): 853-886, http://dx.doi.org/10.5465/AMR.1997. 9711022105.

New Zealand Government (2011) National Infrastructure Plan 2011. New Zealand Government, Wellington, New Zealand. See http://www.infrastructure.govt.nz/plan (accessed 25/01/2016).

OECD (Organisation for Economic Co-operation and Development) (2012) Strategic infrastructure Needs to 2030: Main findings. OECD, Paris, France. See http://www.oecd.org/futures/ infrastructureto2030/49094448.pdf (accessed 15/02/2016).

Omega Centre (2012) Lessons for Decision-Makers: an Analysis of Selected International Large-Scale Transport Infrastructure Projects. Omega Centre, London, UK.
Reason J (1990) The contribution of latent human failures to the breakdown of complex systems. Philosophical Transactions of the Royal Society of London: Biological Sciences 327(1241): 475-484.

Reason J (1995) A systems approach to organizational error. Ergonomics 38(8): 1708-1721, http://dx.doi.org/10.1080/ 00140139508925221.

Schön D (1991) The Reflective Practitioner: How Professionals Think in Action. Ashgate Arena, Aldershot, UK.

Snowden D and Boone M (2007) A leader's framework for decision making. Harvard Business Review 85(11): 68.

Star S (1999) The ethnography of infrastructure. American Behavioral Scientist 43(3): 377-391, http://dx.doi.org/10.1177/ 00027649921955326.

Van de Ven AH (1976) A framework for organization assessment. Academy of Management Review 1(1): 64-78, http://dx.doi. org/10.5465/AMR.1976.4408765.

van der Lei T, Herder P and Wijnia Y (eds) (2012) Asset Management: the State of the Art in Europe from a Life Cycle Perspective. Springer, Delft, Netherlands.

Weber M (1958) The City (Neuwirth DMAG (ed.)). Free Press, New York, NY, USA.

Winter M, Smith C, Morris P and Cicmil S (2006) Directions for future research in project management: the main findings of a UK government-funded research network. International Journal of Project Management 24(8): 638-649, http://dx.doi. org/10.1016/j.ijproman.2006.08.009.

Zylstra G (2013) Struggle over the streets: industrialization and the fight over the corporate control of street space in Philadelphia, 1830-1860. Journal of Urban Technology 20(3): 3-19, http://dx.doi.org/10.1080/10630732. 2013.823052 .

\section{HOW CAN YOU CONTRIBUTE?}

To discuss this paper, please email up to 500 words to the editor at journals@ice.org.uk. Your contribution will be forwarded to the author(s) for a reply and, if considered appropriate by the editorial board, it will be published as discussion in a future issue of the journal.

Proceedings journals rely entirely on contributions from the civil engineering profession (and allied disciplines). Information about how to submit your paper online is available at www.icevirtuallibrary.com/page/authors, where you will also find detailed author guidelines. 